Созонюк Ольга

кандидат психологічних наук, доцент кафедри вікової та педагогічної психології Рівненського державного гуманітарного університету ORCID iD: 0000-0002-6810-6341 DOI https://doi.org/10.35619/prap_rv.vi13.134

\title{
ПСИХОЛОГІЧНІ ОСОБЛИВОСТІ СТАНОВЛЕННЯ ПРОФЕСІЙНОЇ ІДЕНТИЧНОСТІ МАЙБУТНІХ ПЕДАГОГІВ
}

Анотація. Стаття присвячена аналізу психологічних особливостей становлення професійної ідентичності майбутніх педагогів. Професійна ідентичність - ие психологічна категорія, яка відноситься до усвідомлення своєї приналежності до певної професії, певної професійної спільноти. Професійна ідентичність педагога виконує такі функції, як розвиток «професійного почуття», тобто емоційного прийняття себе людиною, яка, займається певною справою, усвідомлення певної ментальності, впевненість у своїй професійній приналежності, самостійності та ефективності, переживання своєї професійної иілісності та визначеності. Професійна ідентичність є необхідною складовою професійного розвитку особистості, становлення професіонала та кар'єрного росту. Формуючи професійну ідентичність майбутні вчителі корегують власний стиль роботи, починають усвідомлювати свої професійні можливості, вчаться управляти розвитком власної кар'єри, підвищують свою професійну компетентність.

Ключові слова: ідентичність, професійна ідентичність, професійне самовизначення, професійна компетентність.

Постановка проблеми. Сучасні процеси державотворення в Україні зумовлюють потребу у новому типові особистості з високим рівнем культури й духовності, яка здатна самостійно приймати рішення, робити свій вибір, адекватно реагувати на зміни обставин, конструктивно впливати на оточення. Виконання цього основного завдання у навчанні та вихованні нового покоління покладається на освітянську галузь. А тому, природно, підвищуються вимоги до рівня професіоналізму, особистісних якостей учителя, який здійснює навчально-виховний процес у школі. Однією із важливих умов професійного розвитку особистості педагога, самопізнання і самовдосконалення у професійній діяльності, професійної реалізації, творчої спрямованості та продуктивності є професійна ідентичність учителя, розвиткові якої має приділятись значна увага ще у процесі професійної підготовки майбутнього фахівця.

Аналіз останніх досліджень 3 проблеми. Центральне місце в професійному становленні учителя займає формування його професійної ідентичності, що є результатом усвідомлення індивідом своєї тотожності з професійною діяльністю та спільнотою, знання меж своєї професійної компетенції та впевненості у своїй ефективності, відчуття себе як професіонала. Так, професійну ідентичність досліджували Волянюк, Срмолаєва, Ложкін, Лукіянчук, Мітіна, Поварєнков та ін. Зокрема, проблему професійно-педагогічної ідентичності вивчали у своїх роботах Абдрашитов, Срмакова, Жигінас, Кузьміна, Павлюк та ін.

Метою статті є вивчення психологічних особливостей становлення професійної ідентичності майбутніх педагогів.

Виклад основного матеріалу дослідження. Варто зазначити, що існують різні точки зору на проблему професійної ідентичності. Дослідження професійної ідентичності деякими вченими рухаються в напряму професійного самовизначення та професійного розвитку. Інші вчені розглядають професійну ідентичність у контексті проблематики професійної самосвідомості. Психологічну концепцію професійної ідентичності обгрунтувала 
Л. Шнейдер. Вона виходить $з$ того, що становлення профідентичності відбувається в межах професії. Поняття «професія» задає змістові характеристики профідентичності. Але професійна ідентичність не зводиться власне до професіоналізму, це результат професійного самовизначення, персоналізації та самоорганізації. Виходячи 3 цього, Л. Шнейдер (2001) визначає професійну ідентичність як психологічну категорію, яка відноситься до усвідомлення своєї приналежності до певної професії, певної професійної спільноти.

Зеєр пропонує інший підхід. Він визначає професійну ідентичність через поняття професійного «образу Я». Зеєр вважає, що професійне становлення особистості супроводжується деструктивними змінами (кризи, стагнація та деформації особистості), що обумовлюють перервність, нерівномірність і гетерохроність професійного розвитку (Зеєр, 2005).

У роботах Іванової професійну ідентичність розглянуто як вид соціальної. Вона вважає, що професійна ідентичність «формується у процесі виявлення суттєвих зв'язків всередині та ззовні професії та відмінності їх як таких, вона пов'язана 3 загальною інформаційною основою діяльності, а також із цілісними еталонами типових професійних подій та індивідуалізованих концептуальних схем професійної поведінки» (Іванова, 2004).

Єрмолаєва трактує професійну ідентичність як компонент особистісної ідентичності, що забезпечує успішну професійну адаптацію, і як домінантний чинник професійної кар'єри, що базується на компетентності, профпридатності, інтересі до роботи та їх балансі 3 оточенням. Але при цьому, вона розширює це поняття до масштабів ідентифікаційних зв'язків людини і з соціальним середовищем. Професійна ідентичність виступає, перш за все, як характеристика внутрішньої відповідності суб'єкта діяльності і соціально-професійного середовища (Срмолаєва, 2008).

У контексті професійної самосвідомості розглядає професійну ідентичність Є. Клімов. Зокрема, він виділяє такі елементи у структурі професійної самосвідомості: усвідомлення своєї приналежності до певної професійної спільноти; знання про ступінь своєї відповідності професійним еталонам, про своє місце у системі професійних ролей; знання людини про ступінь визнання у професійній групі; знання про сильні та слабкі сторони, шляхи самовдосконалення, вірогідних зон успіху та поразки, знання своїх індивідуальних способів успішної дії; уява про себе і свою роботу в майбутньому (Клімов, 1996).

Згідно з поглядами Поваренкова (2006), професійна ідентичність розглядається як явище системне, динамічне і рівневе, тісно пов'язане з іншими елементами професійного розвитку, зокрема, професійним самовизначенням, професійною самооцінкою, професійною деформацією тощо. Ми притримуємося визначення Шнейдер (2001), що професійна ідентичність - це психологічна категорія, яка відноситься до усвідомлення своєї приналежності до певної професії, певної професійної спільноти.

Професійну ідентичність учителя в психолого-педагогічній літературі визначено як інтегральну характеристику особистості. Вона може бути, з одного боку, віднесена до соціальної ідентичності, оскільки не вичерпується прийняттям відповідних професійних ролей та функцій. 3 іншого боку, вона не належить і до самої ідентичності, оскільки ставлення до себе як до професіонала є лише одним із показників сформованості професійної ідентичності. Інтегральність такої характеристики особистості полягає у тому, що у структурі професійної ідентичності представлені обидві форми ідентичності. Професійна ідентичність педагога виконує такі функції, як розвиток «професійного почуття», тобто емоційного прийняття себе людиною, яка, займається певною справою, усвідомлення певної ментальності, впевненість у своїй професійній приналежності, самостійності та ефективності, переживання своєї професійної цілісності та визначеності. Професійну ідентичність характеризує приєднання та накладання образу професії (зі всіма іiі закономірностями) на особливості конкретної особистості (Березіна, 2008).

Феномен професійної ідентичності вчителя основної школи $є$ багатомірним i складним. А це, у свою чергу, означає, що професійна ідентичність не може мати якогось єдиного універсального критерію чи показника. У роботах М. Павлюк представлені критерії становлення професійної ідентичності вчителя основної школи та визначення рівня іiі 
сформованості на основі показників пізнавального, оціночно-ціннісного, конативного критерію. Оціночно-ціннісний критерій визначає ставлення вчителя основної школи до себе як професіонала, рівень самооцінки професійних якостей, інтегральне відчуття за чи проти власного «Я», самовпевненість, аутосимпатію, очікування позитивного ставлення інших, самоінтерес, самоповагу, самоприйняття, самозвинувачення, саморозуміння, ставлення до діяльності. Пізнавальний критерій виявляє знання вираженості своїх професійно важливих якостей, авторитарність, егоїстичні тенденції, агресивність, підозрілість, підпорядковуваність, залежність, доброзичливість, альтруїстичність тощо (Павлюк, 2009).

Конативний критерій оцінює рівень адаптації, самоприйняття, інтегральне прийняття інших, емоційний комфорт, прагнення домінувати, інтернальність, самокерівництво, рівень адаптованості до професії, стратегії поведінки у конфлікті: суперництво, уникнення, компроміс, співробітництво, пристосування.

Розвиток професійної ідентичності вчителя, на думку Н. Жигінас, може відбуватися у таких напрямках:

- розвиток потреб та інтересів;

- формування домагань особистості у плані визначення того, ким та яким людина себе бачить;

- відбувається все більш глибоке усвідомлення себе, своїх можливостей та потреб (Жигінас, 2007).

На думку Павлюк, необхідною умовою розвитку професійної ідентичності вчителя $є$ сама особистість вчителя, особистісний і професійний потенціал, а також спеціальні знання i уміння, необхідні для певного виду діяльності (Павлюк, 2009). Період навчання у вищому навчальному закладі $є$ дуже важливим етапом процесу становлення професійної ідентичності майбутніх педагогів, оскільки майбутній спеціаліст отримує необхідні знання, вміння та навички, знайомиться 3 колегами та переймає їх досвід, уточнює свої уявлення про обрану спеціальність. Так, наприклад, Балицька вказує на актуальність дослідження становлення професійної ідентичності студентів вищого педагогічного навчального закладу.У сучасних умовах суспільний розвиток може здійснювати тільки творчо мисляча, всебічно розвинена особистість. Тому, природно, підвищуються вимоги до особистості вчителя, його психологічного образу та професійної підготовки. Зараз, як ніколи, суспільству необхідні спеціалісти, які поєднують у собі глибоку професійну підготовку, відповідальність, прагнення до оновлення та збагачення своїх знань. Тому особливу увагу необхідно приділяти професійній підготовці майбутнього вчителя, формувати його самосвідомість та професійну само ідентичність. (Балицька, 2002, с.46).

Отже, розвиток професійної ідентичності у майбутнього вчителя - це шлях ототожнення власних індивідуальних властивостей 3 індивідуальними властивостями досвідченого вчителя, які викликають у студентів інтерес, захоплення, стають для нього близькими, зрозумілими і бажаними для майбутньої професійної діяльності. Вивчення особливостей становлення професійної ідентичності студентів педагогічного ВНЗ дає підстави для виокремлення основних етапів цього процесу.

Перший етап - адаптаційний (1 курс). Він характеризується першим знайомством 3 професійною спільнотою, осмисленням професійної ідентичності, входженням у нове соціальне та професійне середовище, що зумовлює перехід зовнішньої ідентичності студента у внутрішньо прийняту, усвідомлену, емоційно забарвлену. Треба зауважити, що цей нестабільний етап, пов’язаний з пристосуванням до нової соціальної ролі студента («Ястудент») та очікувань майбутньої професійної ідентичності.

Початковий етап професійного становлення (вибір сфери діяльності, пошук свого місця у професійному товаристві, соціальна адаптація та самореалізація) дослідники цілком слушно розглядають як ключовий момент, який часто визначає весь хід подальшого життя людини, ii соціальну і професійну ідентичність. Важливою складовою цього етапу $\epsilon$ отримання необхідних знань та формування відповідних умінь, уточнення уявлення про ту діяльність, якій індивід вирішив присвятити себе. Як би там не було, але період студентства $\epsilon$ доволі складним: молода людина, яка перебуває на межі пізньої юності та ранньої зрілості, 
повинна вирішити питання про пріоритетність своїх життєвих цінностей, окреслити найближчі та перспективні цілі. Ось чому наріжним завданням університетської освіти, крім передачі знань та вмінь (інформованості), є також формування особистості-професіонала, забезпечення його самоідентифікації з професією.

Другий етап - стабілізуючий (2-3 курси). На цей період припадає підтвердження чи відкидання первинного вибору. Ясна річ, тут можлива суттєва зміна професійних уподобань і намірів студентів, що пов'язана або із розчаруваннями в зробленому професійному виборі, або, навпаки, із посиленням впевненості в його доцільності. У цьому разі спостерігається прийняття вимог нової соціально-професійної ролі, своїх здібностей та можливостей, усвідомлення досягнень, реалізованих завдяки власним зусиллям. В другому етапі конструктивні схеми саморозвитку перебувають у достатньо стабільному стані, тому що студент починає отримувати задоволення від сприйняття себе як суб'єкта майбутньої професійної діяльності («Я-майбутній учитель»).

Третій етап - уточнювальний (4 курс). Це період, коли на основі усвідомлення спектру ролей, засвоєних у ході професіоналізації, відбувається формування нових цілей та перспектив. Цей етап характеризується нестабільністю, зумовленою переосмисленнями та уточненням різних варіантів професійно-творчого саморозвитку, перейнятістю працевлаштуванням та професійною кар'єрою («Я-моя професія і кар’єра»).

Окреслюючи зазначені етапи формування у студентів педагогічних університетів професійної ідентичності, слід мати на увазі, що вони не існують ізольовано, а навпаки, тісно взаємопов'язані та взаємозумовлені. Зрозуміло, що успішність кожного наступного етапу значною мірою залежатиме від того, наскільки успішно студенту вдалося подолати попередній етап.

Модель формування професійної ідентичності учителя у процесі його вузівської підготовки, як зазначає Березіна $(2008$, с.11), складається 3 трьох факторів та поєднує суб'єктивні, чи особистісні, внутрішні, детермінанти, пов'язані з ціннісно-смисловою сферою, самосвідомістю, самоактуалізацією, рефлексивністю, компетентністю, вміннями, задоволенням, творчістю; об'єктивні чи зовнішні, чинники, пов'язані 3 вимогами професійної діяльності, яка здійснюється в особистісно-орієнтованій парадигмі, що виступає регулюючою основою професійно-особистісного самовизначення вчителя; об'єктивносуб'єктивні чинники (фактори), які пов'язані з організацією освітньої та професійної сфер.

Зміни вимог до рівня кваліфікаційних знань і вмінь майбутніх педагогів, ставлять перед вищою школою завдання готувати фахівців 3 високим рівнем функціональної гнучкості. А для цього необхідні фундаментальні й вузькоспеціальні знання в суміжних галузях наук, навички структурного підходу до розв'язання різних професійних завдань і проблем. Інакше кажучи, кваліфікаційні вимоги виходять за межі професійних стандартів і припускають ширший спектр знань і вмінь. Тому освітня політика має бути поширена на всі життєві стадії індивіда, щоб забезпечити потенціал його професійного і соціального розвитку протягом усього життя. Освіта повинна носити безперервний характер, пов'язаний 3 постійним підвищенням професійної кваліфікації вчителя. Якщо уявити процес впливу змінних зовнішніх чинників на систему вищої педагогічної освіти як взаємопов'язані ланки: соціальні, економічні, політичні зміни ↔ зміни професійних вимог $\leftrightarrow$ зміни в системі вищої педагогічної освіти, можна побачити, що фахівець, який здобув освіту, не тільки «утриматись», а й «закріпитися» в соціальній ієрархії, зміцнити свої позиції в установі, де він працюватиме.

Сучасна система вищої педагогічної освіти має бути спрямована на підготовку фахівця, здатного водночас виконувати конкретний вид діяльності й адаптуватися до змінних соціальних умов. Йдеться про своєрідну «метакваліфікацію», покликану компенсувати професійні недоліки, формувати нові навички й уміння самостійно доповнювати свою кваліфікацію.

Висновки і перспективи подальших розвідок. Отже, проведений теоретичний аналіз психолого-педагогічної літератури дозволяє зробити висновок, що професійна ідентичність майбутнього вчителя - це усвідомлення своєї приналежності професії педагога, 
уявлення про свою відповідність певним вимогам професії (певні якості особистості, знання та вміння) та співставлення своєї відповідності професійному образу. Професійна ідентичність педагога динамічна система, яка починає формуватись у процесі професійної підготовки (освіти) та має подальший розвиток у професійній діяльності. Професійна ідентичність є необхідною складовою професійного розвитку особистості, становлення професіонала та кар'єрного росту. Формуючи професійну ідентичність, майбутні вчителі корегують власний стиль роботи, починають усвідомлювати свої професійні можливості, вчаться управляти розвитком власної кар'єри, підвищують свою професійну компетентність.

\section{СПИСОК ПОСИЛАНЬ}

Балицкая, Н. Н. (2002). Формирование самоидентичности у будущих педагогов в процессе профессиональной подготовки. ПостМетодика. Роль антропологічного фактора в освітніх технологіях ХХІ століття, 7-8, 241-244.

Березина, Т. С. (2008). Становление профессиональной идентичности педагога. Педагогическое образование и наука, 7, 24-27.

Ермолаева, Е. П. (2008). Психология социальной реализации профессионала. Москва: Институт психологии РАН.

Жигинас, Н. (2007). Этапь формирования профессиональной идентичности педагога. Москва: Наука.

Зеер, Е. Ф. (2005). Психология профессий. Москва: Фонд "Мир".

Иванова, Н. Л. (2004). Профессиональная идентичность и профессиональное пространство. Мир психологи, 2, 148-156.

Климов, Е. А. (1996). Психология профессионала. Москва: ИПП.

Павлюк, М. М. (2009). Розвиток професійної ідентичності педагога як чинник попередження дезадаптації школярів. Проблеми загальної та педагогічної психологї, XI, 6, 318-327.

Поваренков, Ю. П. (2006). Введение в психологию труда. Киров.

Шнейдер, Л. Б. (2001). Профессиональная идентичность. Москва: МО-СУ.

\section{REFERENCES}

Balitskaya, N. N. (2002). Formirovaniye samoidentichnosti u budushchikh pedagogov v protsesse professionalnoy podgotovki. PostMetodika. Rol antropologichnogo faktora $v$ osvitnikh tekhnologiyakh XXI stolittya, 7-8, 241-244. [in Russian].

Berezina, T. S. (2008). Stanovleniye professionalnoy identichnosti pedagoga. Pedagogicheskoye obrazovaniye i nauka, 7, 24-27. [in Russian].

Ermolayeva, E. P. (2008). Psikhologiya sotsialnoy realizatsii professionala. Moskva: Institut psikhologii RAN. [in Russian].

Zhiginas, N. (2007). Etapy formirovaniya professionalnoy identichnosti pedagoga. Moskva: Nauka. [in Russian].

Zeyer, E. F. (2005). Psikhologiya professiy. Moskva: Fond "Mir". [in Russian].

Ivanova, N. L. (2004). Professionalnaya identichnost i professionalnoye prostranstvo. Mir psikhologii, 2, 148-156. [in Russian].

Klimov, E. A. (1996). Psikhologiya professionala. Moskva: IPP. [in Russian].

Pavlyuk, M. M. (2009). Rozvitok profesiynoï identichnosti pedagoga yak chinnik poperedzhennya dezadaptatsiï shkolyariv. Problemi zagalnoï ta pedagogichnoï psikhologiï, XI, 6, 318-327. [in Ukrainian].

Povarenkov, Yu. P. (2006). Vvedeniye v psikhologiyu truda. Kirov. [in Russian].

Shneyder, L. B. (2001). Professionalnaya identichnost. Moskva: MO-SU. [in Russian]. 


\title{
PSYCHOLOGICAL FEATURES OF ESTABLISHING OF THE PROFESSIONAL IDENTITY OF FUTURE TEACHERS
}

Olha Sozoniuk

Candidate of psychological sciences, Associate Professor of Department of Lifespan \& Pedagogical Psychology

Rivne State University of the Humanities

ORCID iD : 0000-0002-6810-6341

DOI https://doi.org/10.35619/prap_rv.vi13.134

\begin{abstract}
The article is devoted to the analysis of psychological peculiarities of future educators' professional identity formation. Professional identity is a psychological category that refers to the awareness of the profession of a person who belongs to a particular professional community. The professional identity of the teacher in the psychological and pedagogical literature is defined as an integral characteristic of an individual. On one hand, it can be related to social identity because it is not depleted by the adoption of appropriate professional roles and functions. On the other hand, it does not belong to the identity itself, since the attitude towards oneself as a professional is only one of the indicators of the formation of professional identity. The integrality of such a personal characteristic is that both forms of identity are represented in the structure of professional identity.

The professional identity of the teacher performs such functions as the development of "professional feeling", for exmple emotional acceptance of a person who is engaged in a particular business, awareness of a certain mentality, confidence in their professional identity, independence and efficiency, the experience of their professional integrity and determination.

Professional identity is a necessary part of personal professional development, becoming a professional and career development. By forming a professional identity, future teachers adjust their own style of work, become aware of their professional opportunities, learn to manage their own career development, and increase their professional competence.
\end{abstract}

Key words: professional orientation, vocational and educationalorientation, professional identity, professional marginalism. 